\title{
Role of Self Help Groups in Women Empowerment and Health
}

\author{
H.A. Manvar ${ }^{1}$, J.B. Kathiriya ${ }^{2 *}$ and D.S. Thakar ${ }^{1}$ \\ ${ }^{1}$ Krishi Vigyan Kendra, Junagadh Agricultural University, \\ Targhadia-Rajkot (Gujarat)-360003, India \\ ${ }^{2}$ Department of Veterinary Public Health \& Epidemiology, Veterinary College, \\ Junagadh Agricultural University, Junagadh-362001, India \\ *Corresponding author
}

\section{A B S T R A C T}

Self-help groups (SHGs) are small voluntary association of people from the same socioeconomic background with a purpose of solving their common problems through self-help and mutual help. Since Women empowerment and health are interrelated -women's

\section{Keywords}

Self -help group, Women's empowerment, Health

Article Info

Accepted:

12 March 2019

Available Online:

10 April 2019 empowerment cannot be achieved by ignoring issues related to health of women. There have been fewer attempts to address the issue of women's health so as to have an impact on their total wellbeing. Hence the present study intends to explore the extent to which self-help groups are involved in health and also identify other possible methods to increase their involvement in health related matters. A Community based cross sectional study was conducted in rural area of Rajkot district of Gujarat, India. 120 women who were involved in SHG for 1 year were interviewed by a pre- validated questionnaire. Out of 120 women 110 were interviewed, $63.64 \%$ were literates, $66.48 \%$ received economic help through this programme, $28.50 \%$ got importance in family as well as community, $21.40 \%$ had improvement in personal health, $70.50 \%$ of individuals self decides to seek medical care for health related issues. Self-help group is a useful platform to enhance women's health through increased knowledge and awareness on health issues, and financial security during health emergencies etc. it's very active in providing income generating activities. However there is no much significant improvement in health behaviour or knowledge about health related issues.

\section{Introduction}

Self-help groups (SHGs)-small voluntary association of people from the same socioeconomic background with a purpose of solving their common problems through selfhelp and mutual help. " In India, self-help groups are women oriented and most of their activities are concentrated towards savings and credit activities. ${ }^{2}$
There is a common perception in development literature that increased participation of women in savings and credit activities or economic attainment will empower women and it is an effective tool to alleviate poverty and empower women has garnered considerable interest worldwide. ${ }^{3}$

There is also the perception that economic attainment will empower women's status in 
family and in the community, giving them more power to participate in decision-making process. ${ }^{4}$

In the context of women's empowerment, it is assumed that when women come together, they find strength and move towards further knowledge and awareness. This process leads to further empowerment.

Thus, collective action through self-help groups introduces an element of leadership, reduces risk and external threat, and enables women to overcome the oppression of patriarchy, and to realise their own true potential and achieve total well-being. ${ }^{3,5}$

Women's empowerment cannot be achieved by ignoring or denying issues related to health of women. Although women's empowerment has been a central issue on the agenda of various developmental programmes for so many years, women's health has got little attention or at best it has been confined to the field of family planning and contraception. ${ }^{6}$

Hence the present study intends to explore the extent to which self-help groups are involved in health and also identify other possible methods to increase their involvement in health related matters.

\section{Materials and Methods}

A Community based cross sectional study was conducted in urban and rural area of Rajkot district of Gujarat during January to June 2015. Out of 15 functioning SHG's, 9 groups were selected by simple random method. 110 women from those selected group who were involved in SHG's for a period of 1 year and who were willing to participate were interviewed by using a pre-validated questionnaire. Data was analysed using Epi info version 7 and Microsoft excel version 2007.

\section{Results and Discussion}

Out of 120 women who were involved in selfhelp group for 1 year were interviewed, $63.64 \%$ (70) were literates and 36.37 (40) were illiterates as depicted in the Figure 1.

Majority of the respondents gained economic help through self-help group (66.48\%), 28.3\% had saved money followed by which $7.2 \%$ had economic independence, $28.5 \%$ got importance in family as well as community, 47.5\% had employment opportunity partially, $79.8 \%$ majority of the respondents had better relations and more friends compared to study conducted by Kumar A et. al; showed 54\% had economic help $16 \%$ had employment opportunity and $76 \%$ had got importance in family $^{4}$ (Fig. 2)

Regarding the impact of self-help group on health knowledge and awareness, 68.5\% had increase awareness regarding health and hygiene, (compared to study by Kumar et al where increased awareness was 70\%), 63.2\% had knowledge regarding contraceptive methods, 51.5\% had increased knowledge and awareness regarding care during pregnancy, followed by care of self-post child birth (52.6 $\%$ ) and $60 \%$ had increased knowledge towards infant care ${ }^{4}$ (Fig. 3).

Impact of self-help group on empowerment and health-regarding decision of seeking medical care and consulting doctor, $67.4 \%$ take self-decision on going to doctor, followed by $22 \%$ whose husband take decision regarding consultation of doctor. $24.2 \%$ of women discuss with their husband about reproductive health issues, compared to study conducted by Kumar et al which showed $38 \%$ who would discuss reproductive health issues with their husband ${ }^{4}$ (Fig. 4; Table 1 and 2). 
Table.1 Illustrating the fully and partial impact of self-help group on women's empowerment

\begin{tabular}{|c|c|c|c|}
\hline & Fully & Partly & Unnoticeable \\
\hline $\begin{array}{l}\text { Increase in } \\
\text { income }\end{array}$ & - & $53.3 \%$ & $46.7 \%$ \\
\hline \multirow{2}{*}{$\begin{array}{l}\text { Employment } \\
\text { opportunity }\end{array}$} & - & $47.3 \%$ & $52.7 \%$ \\
\hline & & & \\
\hline $\begin{array}{l}\text { Got importance } \\
\text { in family }\end{array}$ & $27.3 \%$ & $65.3 \%$ & $7.4 \%$ \\
\hline $\begin{array}{l}\text { Got importance } \\
\text { in community }\end{array}$ & $27.5 \%$ & $67.2 \%$ & $5.3 \%$ \\
\hline $\begin{array}{l}\text { Family } \\
\text { empowerment }\end{array}$ & - & - & $100 \%$ \\
\hline $\begin{array}{l}\text { Cooperation in } \\
\text { social processes }\end{array}$ & $74.5 \%$ & $24.5 \%$ & - \\
\hline $\begin{array}{l}\text { Better relations } \\
\& \text { more friends }\end{array}$ & $80.5 \%$ & $19.5 \%$ & - \\
\hline \multirow{2}{*}{$\begin{array}{l}\text { Improvement in } \\
\text { personal health }\end{array}$} & $22.5 \%$ & $65.5 \%$ & $12 \%$ \\
\hline & & & \\
\hline $\begin{array}{l}\text { Improvement in } \\
\text { family health }\end{array}$ & $18.9 \%$ & $53.7 \%$ & $27.4 \%$ \\
\hline
\end{tabular}

Table.2 Depicting the impact of self-help group on health knowledge and awareness

\begin{tabular}{|l|c|c|c|}
\hline & Increase & Decrease & $\begin{array}{c}\text { No } \\
\text { change }\end{array}$ \\
\hline Health and Hygiene & $68.5 \%$ & -- & $31.5 \%$ \\
\hline Vaccination & $79 \%$ & -- & $21 \%$ \\
\hline Contraceptives & $63.2 \%$ & & $36.8 \%$ \\
\hline $\begin{array}{l}\text { Care during } \\
\text { pregnancy }\end{array}$ & $51.5 \%$ & -- & $48.5 \%$ \\
\hline $\begin{array}{l}\text { Care of self-post } \\
\text { child birth }\end{array}$ & $52.6 \%$ & & $47.4 \%$ \\
\hline Care of Infant & $60 \%$ & -- & $40 \%$ \\
\hline
\end{tabular}


Fig.1 The literacy status of women involved in self-help group

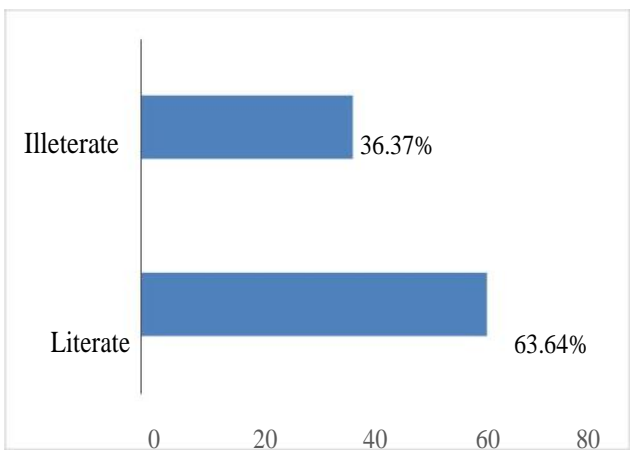

Fig.2 Impact of self-help group on women's empowerment

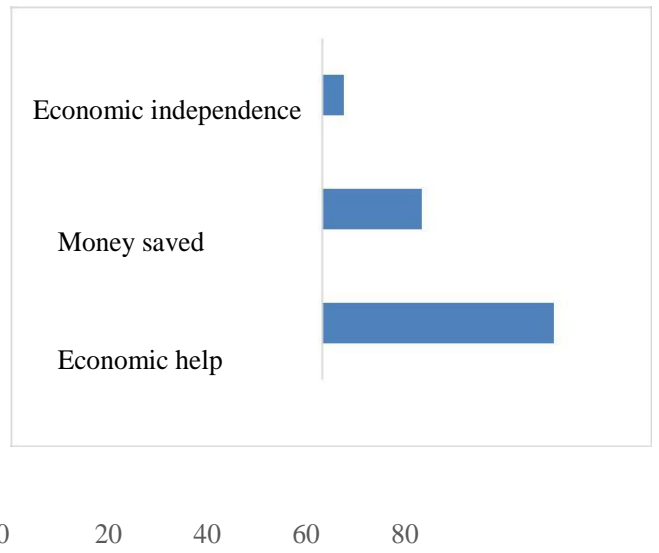

Fig.3 Impact of SHG on empowerment and health

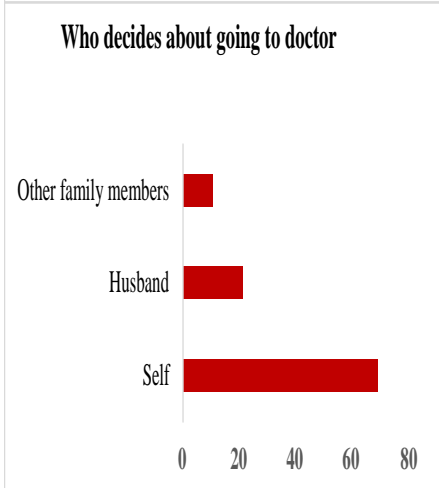


Fig.4 Depicting percentage of women who discusses about reproductive health issues with their husband

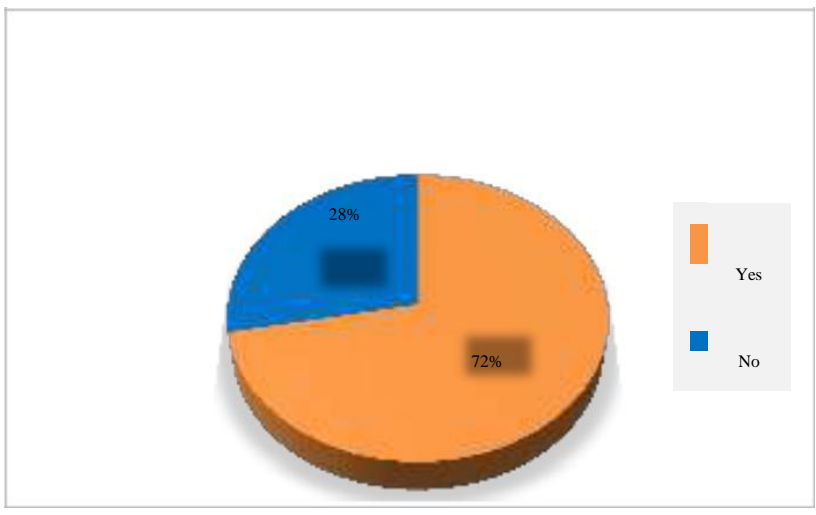

Do you and your husband ever discuss about your reproductive health issues

From the present study we can conclude that self-help group is a useful platform to enhance women's health through increased knowledge and awareness on health issues, and financial security during health emergencies etc. it's very active in providing income generating activities. However there is no much significant improvement in health behaviour or knowledge about health related issues similar findings were seen in Kumar A study. ${ }^{4}$ Hence it is essential to involve the entire community and sensitize men on issues of gender equity. SHGs can play an important role in creating awareness on health issues through group meetings with women, by holding specific capacity-building trainings with the women on health issues.

\section{References}

1. Drdachamba.org. District Rural Development Agency, Chamba. 2016.
Available at http: //drdachamba.org /schemes/SHGs/start.htm. Available at 1 November 2015.

2. Chakravarty, S, Jha A. Health care and women's empowerment: the role of self help groups. HCS. 2012; 2(1).

3. National Policy for Empowerment of Women. (2001). New Delhi: Department of women and child development. Ministry of HRD.

4. Kumar, A. Health inequity and women's self-help groups in India: The role of caste and class. Health Sociology Review. 2007; 16(2): 160-8.

5. United Nations Development Program. Available at http://www.undp.org/ .../documents/.../00049804_Proje ct\%20Document-\%206. Accessed on 21 November 2015.

6. Women's Political Participation: Issues and Challenges. Available at http:// www.un.org/womenwatch/daw/egm/ enabling-environment 2005

\section{How to cite this article :}

Manvar, H.A., J.B. Kathiriya and Thakar, D.S. 2019. Role of Self Help Groups in Women Empowerment and Health. Int.J.Curr.Microbiol.App.Sci. 8(04): 1613-1617.

doi : https://doi.org/10.20546/ijcmas.2019.804.187 